\title{
The Spatial Thinking Ability Students on the Character of Urban and Rural Environments in Solving Population Problems
}

\section{Purwanto PURWANTO ${ }^{1}$ \\ Universitas Negeri Malang, INDONESIA}

\section{Daniar YULISTIYA ${ }^{5}$}

Universitas Negeri Malang, INDONESIA

\author{
Sugeng UTAYA ${ }^{2}$ \\ Universitas Negeri \\ Malang, INDONESIA
}

\author{
Budi HANDOYO ${ }^{3}$ \\ Universitas Negeri \\ Malang, INDONESIA
}

\author{
Syamsul BACHRI ${ }^{4}$ \\ Universitas Negeri Malang, \\ INDONESIA
}

\author{
Saiful AMIN ${ }^{6}$ \\ Universitas Islam Negeri Maulana Malik Ibrahim Malang, \\ INDONESIA
}

\begin{abstract}
${ }^{1}$ Corresponding author: Ph.D Candidate, M.Si, Universitas Negeri Malang, Faculty of Social Science, Department of Geography Education, , E-mail: purwanto.1707219 [at] students.um.ac.id, ORCID: 0000-0001-5434-4528

${ }^{2}$ Prof. Dr., M.Si, Universitas Negeri Malang, Department of Geography Education, Semarang Street 5, Malang, Indonesia, E-mail: sugeng.utaya.fis [at] um.ac.id, ORCID: 0000-0003$3239-5273$

${ }^{3}$ Dr., M.Pd, Universitas Negeri Malang, Department of Geography Education, Semarang Street 5, Malang, Indonesia, E-mail: budi.handoyo.fis [at] um.ac.id, ORCID: 0000-0001-73522932

${ }^{4}$ S.Si, M.Sc., Ph.D, Universitas Negeri Malang, Department of Geography Education, Semarang Street 5, Malang, Indonesia, E-mail: syamsul.bachri.fis [at] um.ac.id, ORCID: 00000003-4576-5616

${ }^{5}$ S.Pd, Universitas Negeri Malang, Department of Geography Education, Semarang Street 5, Malang, Indonesia, E-mail: daniar.yulistiya.1607216 [at] students.um.ac.id, ORCID: 00000002-9612-5531

${ }^{6}$ Ph.D Candidate, M.Pd, Universitas Islam Negeri Maulana Malik Ibrahim Malang, Department of Social Science Education, Gajayana Street 50, Malang, Indonesia, E-mail: amin.geo87 [at] pips.uin-malang.ac.id, ORCID: 0000-0001-5408-2898
\end{abstract}

\section{Abstract}

The purpose of this study is 1) to determine differences in the characteristics of the spatial thinking ability of students in urban and rural school environments and 2) to determine differences in the characteristics of the spatial thinking ability of the sudents in the urban and rural school environments in terms of the type of gender. This research uses experiment methods with a population of class XI students of Social Science both in urban and rural schools with a total sample of 31 students from each school. Spatial thinking skills are measured through the test of problem solving using the satellite imagery of Google Earth as a tool of representation. Spatial thinking skills assessment is based on the components of spatial thinking. It includes understanding concepts of spatial, the use of representation tools, and reasoning process. The data analysis uses statistical for different test with SPSS 25.0 for windows. The results showed, first, spatial thinking ability character's between students in the urban and rural environments are significantly differences. So, the character of environment, i.e., urban and rural is not always consistent in influencing the spatial thinking ability of the students. Second, no differences in the spatial thinkingability in the statistics between male and female students. However, the students in urban environment have the characteristics of spatial thinking better than the students in the rural environment. Female students in urban environment have more powerful character of spatial thinking skills, though it is not proven in male students.

\section{Keywords}

Character, Population Problem Solving, Spatial Thinking Skills, Urban and Rural Environment 
One of the characteristics of geography is the use of spatial thinking as an orientation in problem solving. Spatial thinking is one of the thinking skills using concepts of space, tools of representation and process of reasoning as a basis in solving the problems of life (National Research Council, 2006). Those three components are constant because they affects the success of a person in performing spatial thinking (Sinton, 2015). People who do spatial thinking can be seen from the way they think and act (Bednarz \& Lee, 2011). However, in reality, many people are not aware with this.

The practice of spatial thinking in the realm of Geography Education have been enormously carried out. There are fundamental reasons of why this practice of thinking is used, namely through the practice of spatial thinking, students can visualize and analyse the spatial relationships between objects, such as location, distance, direction, shape, and pattern (Bednarz \& Lee, 2011), as well as understand the various forms of geographical data (Marsh \& Alagona, 2018). Similarly, the ability of spatial thinking is closely related to daily life, because what we do in life always make use of spatial thinking. However, this condition is not widely recognized by many people, that what they do involve the spatial thinking skills.

Spatial thinking in the learning of Geography becomes one of the important skills that need to be mastered by students to solve problems, since both of them have a strong correlation (Metoyer et al., 2016). The correlation can be seen from the needs of spatial representation in geography content (Metoyer et al., 2016). The correlation of spatial thinking skills for problem solving has been delivered earlier (Golledge, 2002; Jackson, 2006; Uhlenwinkel, 2013). This relationship is further used as a basis to think and act geographically. Act geographically is intended to solve the problem using the geographical point of view (Uhlenwinkel, 2013).

Spatial thinking is one form of flexible thinking that can be applied to school learning. In its application, there are several components and parameters which was emphasized by some experts. As for the difference of opinion lies in the translation of the component contents of the spatial thinking concept. However, from this difference, it has been agreed upon key components used as a framework for spatial thinking, namely the understanding of space, tools of representation, and processes of reasoning (National Research Council, 2006; Seyhan, 2019). From this framework, some experts have developed a variety of spatial thinking indicators (Golledge, 2002; Bednarz \& Lee, 2011; Goodchild, 2011) that shows the difference in the subcategories. These differences show that the indicator of spatial thinking is quite flexible to use. The flexibility use of spatial indicators is highly dependent of the content of the material studied. This research was conducted using the indicator of spatial thinking (location, region, density, movement, maps and the spatial distribution, plan, and predict for the material dynamics of the population.

Spatial thinking has several benefits for students, among others, 1) the student is able to present the relationship between objects, 2) the student is able to understand and analyse the arrangement of objects in space, and 3) students were able to draw conclusions in the form of problem solving and decision making (National Research Council, 2006). There is the fact that students with high spatial skills showed better learning on the topic of math and science (Newcombe, 2016). Some of these benefits are able to make students interpret the spatial problem and give a conclusion in the form of answers from issues that have been studied (Elbay, 2020). The importance of spatial thinking skills in learning 
geography becomes the basis for doing the variation learning using geospatialinformation-based technology.

Building the spatial thinking skills of students need a technology-based geospatial equipment as a support to the learning process. There are linkages between spatial thinking skills, student interaction and geospatial technology (Schultz et al., 2008). The use of geospatial technology in learning can improve the skills of spatial thinking significantly (Jo, Hong, \& Verma, 2016). Google Earth is a geospatial technology that has a great potential as a supporting tool in the process of learning geography (Patterson, 2007). The use of Google Earth in the process of geography learning is in accordance with the challenges of the 21 st century which requires students to be able to understand media literacy and ICT Literacy (National Research Council, 2006)). In line with the statement, Google Earth has strengths such as its ability to facilitate students to observe, analyze, and find the natural phenomena on the surface of the earth that are associated with Geography learning (Bailey, Whitmeyer, \& De Paor, 2012). The ease provided by Google Earth is able to make students perceive the learning experience differently.

The rapid development of Google Earth geospatial technology is started to spread in the world of education. The advancement of the information and data affects the emergence of educational resources that can be accessed by everyone (Belgiu et al., 2015). Geospatial technology is one tool that can be used in geography learning, it is related to the concept of GIS which provides a digital representation of the earth in the form of features (Gis, 2008). Associated with the development of geospatial technology, the understanding and the use of such technologies in some areas indicates the presence of differences. As a research of technology-based curriculum implementation, the geospatial technology is considered effective in improving the ability of spatial thinking of students by using imagery (Bodzin, 2011). In addition, Xiang \& Liu (2017) explain there is an influence of Google Earth to spatial ability of students in recognizing the temporal spatial changes. It means environment and mastery of technology factors have a positive influence on the ability of spatial thinking.

The learning environment dramatically affect the outcome of student learning. According to Sartain (expert of American psychology), what is meant by environment includes the conditions and the nature of this world which is in certain ways affect our behavior, growth, development or life processes. Although the environment is not responsible for the maturity of the students, the environment becomes one of the factors that provide a positive influence on learning (Birgili, 2015; Mosharraf \& Tabaeian, 2014). Basically, the environment covers: 1. Place (the physical environment); the state of the climate, the state of the soil, the state of nature; 2. Culture (cultural environment); with the cultural heritage of a certain language, art, economy, science, way of life, religious; 3 . The group of living together (the social environment or the community) family, play groups, and gathered (Umanailo, 2016). The environment referred to in this research is the characteristics of the spatial environment of students that characterize the status of the student's residence namely, rural and urban, including all the environmental elements in it.

The problem of population is one of the materials studied in geography in high schools. It is important to study such material because there are linkages between the physical and the social environment. The National Geography Standards for Life (Heffron, 2012) emphasizes two main perspectives that are used in geography to understand and interpret 
the world: spatial and ecological perspective. The statement explicitly reads: that the spatial dimensions can be constructed from human experience in the space and the place where they live. People who have a habit of asking about what, when and where, is stated that the person has a spatial perspective. From these statements, it can be concluded that the differences in the character of spatial environment and place affect to the ability of a person in the practicing spatial thinking in life.

The complexity of the population problems in the city demands the active involvement of students in solving problems in their environment. Population density, congestion, crime, poverty is identical to the life in the city. This condition is a little different when compared with the rural environment with strong values of life and a strong kinship which can affect the character of the people in the practice of spatial thinking in life. Spatial thinking is one of the thinking skills linked to everyday life. Such complexity leads to variations in the spatial thinking skills of the urban and rural students (Erdoğan, 2019).

In addition to being influenced by environmental factors, the mastery of geospatial technologies, other factors which also affect the ability of spatial thinking is gender (King, Katz, Thompson, \& Macnamara, 2019). Some researchers argue that gender differences are intrinsically affect the spatial thinking of a person. Males naturally have the ability to think spatially more superior than females (Battista, 2012). This thinking ability is constantly increasing as people get older (Lauer et al., 2019). Based on this, biological condition also influences the ability of spatial thinking. Men tend to have a big development in the right hemisphere of brain, it causes male to be dominant in the imagination of visual spatial compared with women (Yilmaz, 2009). Significant differences that favor males in the task of Visual Spatial Working Memory (VSWM) (Bosco et al., 2004), did not consistently affect the ability of spatial thinking (SanchisSegura, Aguirre, Cruz-Gómez, Solozano, \& Forn, 2018).

Sex differences on some research related to spatial thinking skills showed inconsistent results. This development led to the ability to think spatially is still an interesting debate to study. Yet the number of studies that integrate between the character of the environments, gender and mastery of geospatial technology of Google Earth in influencing spatial thinking skills become a problem that is interesting to study more in depth.

Prepare students to think spatially using Google Earth as a tool of representation in teaching and learning geography is an interesting challenge if used on a different character environment. Based on this, this study aims to answer the following problems:

- Are there any differences in the characteristics of the spatial thinking skills of students in urban and rural school environments?

- Are there any differences in the characteristics of the spatial thinking skills of the students in the urban and rural school environments in terms of the type of gender?

\section{Methodology}

\section{Research Design}

This research is quasi-experimental research by applying post-test only control group design. The research was conducted on 2 schools with different environment characters. SMAN 6 of Malang City, Indonesia is the school with the urban environment and SMAN 1 Tumpang, Indonesia is a school with the character of a rural environment. Both schools 
introduced identical system of learning in terms of models, methods, media and indicators of spatial thinking. The learning model used is problem solving using Google Earth as the tools of representation, which is applied on the material of population dynamics. The draft of the research design is carried out as follows.

Table 1

Experiment Research Design

\begin{tabular}{lll}
\hline Class & Treatment & Posttest \\
\hline E1 & $\mathrm{X}$ & $\mathrm{O}$ \\
\hline E2 & $\mathrm{X}$ & $\mathrm{O}$ \\
\hline E1 & : Group Class of School Experiment in an urban environment & \\
E2 & : Group Class of School Experiment a rural environment & \\
$\mathrm{X}$ & $:$ Treatment to the use of Google Earth representation tools & \\
$\mathrm{O} \quad:$ The ability of spatial thinking test &
\end{tabular}

Stages of implementation in this study begins by giving a stimulus to students regarding the application of Google Earth, provide guidance material, and continued to the stage of investigation includes the activities of identification, observation, discovery, and perform spatial reasoning.

\section{Participants}

The subjects of this study stand from 62 students comprised of 31 students in urban and rural school, respectively. Both sample classes are determined by purposive sampling on the basis of equivalent ability. These capabilities can be seen from the results of the average value of student's daily test of the on previous material. Both sample classes are further differentiated based on the gender. In the following part is presented the table details of the participants in this study.

Table 2

Participants

\begin{tabular}{ccccc}
\hline \multirow{2}{*}{ School } & \multirow{2}{*}{ Regions } & \multicolumn{2}{c}{ Gender } & Total \\
\cline { 3 - 5 } & & Female & Male & \\
\hline Urban School & Malang City & 18 & 13 & 31 \\
& & $(58,06 \%)$ & $(41,9 \%)$ & $(100 \%)$ \\
\hline Rural School & Tumpang Sub-district & 20 & 11 & 31 \\
& & $(64,5 \%)$ & $(35,5 \%)$ & $(100 \%)$ \\
\hline
\end{tabular}

\section{Data Collection}

Google Earth in this research is a technology that provides data satellite imagery as a representative tool to understand the problem of population in urban and rural environments. The data used in this study is quantitative data in the form of the value of spatial thinking skills obtained after administering tests or the written exams. Those tests are in the form of the questions essay contains 9 questions that involve the components of the spatial thinking sub indicators. Data analysis techniques in this study using the test of independent sample t-test using SPSS 25 for windows which is used to determine the difference in the influence of Google Earth media use on the material of population dynamics on the spatial thinking ability of students in schools in urban and rural environments in Malang. 
Table 3

The Indicator of Spatial Thinking Ability

\begin{tabular}{|c|c|c|}
\hline No. & Spatial Thinking Ability & Sub Indicators \\
\hline \multirow[t]{4}{*}{1.} & Spatial Concept & - Location \\
\hline & & - Space \\
\hline & & - Density \\
\hline & & - Movement \\
\hline 2. & Representative Tools & - Google Earth satellite imagery \\
\hline \multirow[t]{2}{*}{3.} & Process of Reasoning & - Predictions \\
\hline & & - Planning \\
\hline
\end{tabular}

Data Analysis

Analysis of differences in the characteristics of spatial thinking skills of students in urban and rural environment. This research uses the hypothesis test is the independent samples t-test. Normality test in this study using the Kolmogorov Smirnov test, while homogeneity test in this research uses homogeneity test. The third test data was processed using SPSS 25 for windows.

Analysis of differences in the characteristics of spatial thinking skills of students in urban and rural environments in terms of gender types. To see the in-depth difference of the characteristics of spatial thinking skills among students in the urban and rural school environments, a review based on the type of gender was conducted. Differences in the characteristics of spatial thinking skills between male and female students in urban and rural environment is done by using Independent samples t-test. Advanced analysis is performed to determine in depth difference between male students in urban environment and male students in the rural as well as between female students in urban and rural environment in their spatial thinking ability by using the MannWhitney test, since the results of data precondition test are not normal or showing the results of below 0.05 .

\section{Procedure}

In the process of learning, the issues of population are presented on both the characteristics of the region leads to the mobility and the density of the population materials. Stages of the learning activities conducted for the students in the experimental class are:

Experiment learning activities in the school on the character of the urban environment: Teacher and students perform an orientation to the population problems using Google Earth. 


\begin{tabular}{cccccc}
\hline & & & $(\%)$ & (student) & $(\%)$ \\
\hline$<39$ & Not Good & 0 & 0 & 0 & 0 \\
\hline $40-54$ & Less & 1 & 3 & 0 & 0 \\
\hline $55-69$ & Enough & 3 & 10 & 14 & 45.16 \\
\hline $70-84$ & Good & 10 & 32 & 15 & 48.39 \\
\hline $85-100$ & Very Good & 17 & 55 & 2 & 6.45 \\
\hline & Total & 31 & 100 & 31 & 100 \\
\hline
\end{tabular}

Table 4 above shows the results of spatial thinking ability test of students from the experimental class in the urban and rural school areas. The results of spatial thinking skills tests show the difference. The ability of spatial thinking in the school with the character of the Urban environment is dominated by the category of very good by $55 \%$. While the results of the ability test of spatial thinking of the students at the school with the characteristics of the rural environment is dominated by the good category with a percentage of $48.4 \%$. Based on the mentioned distribution, the students in the school with the character of the urban environment is superior when compared to students in the school with the character of the rural environment. It can be seen from the number of students who obtain very good category.

Table 5

Result Distribution of Indicator Achievement of Students Spatial Thinking Ability

\begin{tabular}{|c|c|c|c|c|c|c|}
\hline \multirow{2}{*}{ No. } & \multirow{2}{*}{ Indicators } & \multirow{2}{*}{$\begin{array}{c}\text { Sub } \\
\text { Indicators }\end{array}$} & \multirow{2}{*}{ Score } & \multicolumn{2}{|c|}{ Average } & \multirow{2}{*}{ Difference } \\
\hline & & & & Urban Schools & Rural Schools & \\
\hline \multirow[t]{4}{*}{1.} & \multirow[t]{4}{*}{ Spatial Concept } & Location & 10 & 7 & 8,8 & 1,8 \\
\hline & & Space & 10 & 10 & 3,53 & 6,47 \\
\hline & & Density & 10 & 9 & 4,2 & 4,8 \\
\hline & & Movement & 25 & 18 & 6,6 & 11,4 \\
\hline 2. & Representative Tools & Google Earth & 15 & 8 & 13 & 5 \\
\hline \multirow[t]{2}{*}{3.} & \multirow[t]{2}{*}{ Process of Reasoning } & Planning & 15 & 11 & 7,1 & 3,9 \\
\hline & & Predictions & 15 & 9 & 13 & 4 \\
\hline Tota & & & 100 & & & \\
\hline
\end{tabular}

Table 5 shows the results of the indicator achievement of students spatial thinking ability of the experimental class in the school of urban and rural environments. Based on the table, it is known that urban schools are superior on ability indicators of regional spatial thinking, density, movement, map and plan. While the rural school is superior in location indicators, the use of representation tools and prediction. The result shows that those two schools have a difference of achievement results of the spatial thinking ability. The hypothesis test is performed using independent sample t-test. The results of those tests can be seen in Table 6 below.

Table 6

Test Results of Independent Sample t-test

\begin{tabular}{llcc}
\hline \multirow{2}{*}{$\begin{array}{l}\text { Spatial Thinking } \\
\text { Ability }\end{array}$} & School & Mean & Sig. \\
\cline { 2 - 4 } & Urban environmental character & 82 & 0.000 \\
& Rural environmental character & 72 & 0.002 \\
\hline
\end{tabular}

Based on the results of data analysis obtained a significance value of 0.000 for the students at the school with the character of the urban environment and 0.002 for the student with the character of the rural environment. If viewed from the level of signification, the character of the environments does not affect the differences in the 
ability of spatial thinking, because they both demonstrate high ability of spatial thinking. Although not proven statistically, students in the urban environment are superior in solving spatial problems. However, from those two schools have character difference in spatial thinking.

\section{The Characteristics of the Spatial Thinking Skills of Students is Reviewed from the Gender Perspective in the Urban and Rural School Environment}

There are several factors that affect the spatial thinking ability. This study will discuss the results of the distribution of the spatial thinking skills of the students of the experimental class based on the type of gender. Gender is one of the factors that is often associated with the ability of spatial thinking of students. Some theory states that the spatial thinking skills of male students are better when compared with girls. According to Lauer et al. (2019), in some of the tasks associated with spatial, males are consistently and significantly better when compared to females (Linn \& Petersen, 1985). Meanwhile, according to Newcombe, Bandura, \& Taylor (1983) gender differences can be influenced by personality (biological), social environment and spatial experience. The results of the indicator achievement data of students spatial thinking ability taken from the experimental class based on the type of gender are presented in figure 3.

Figure 3 shows a diagram of the indicator achievement of the students spatial thinking skills reviewed from the gender perspective. The diagram shows that female student is superior in five indicators of spatial thinking skills, namely identifying the location, performing calculations, distributing the results on a map skill, explaining the factors causing the problems, and planning solutions. While male students were superior in four indicators of the of spatial thinking ability such as determining the location, reading the orientation and explaining the causal factors based on the region, explaining the pattern, and predicting problems in the future. 


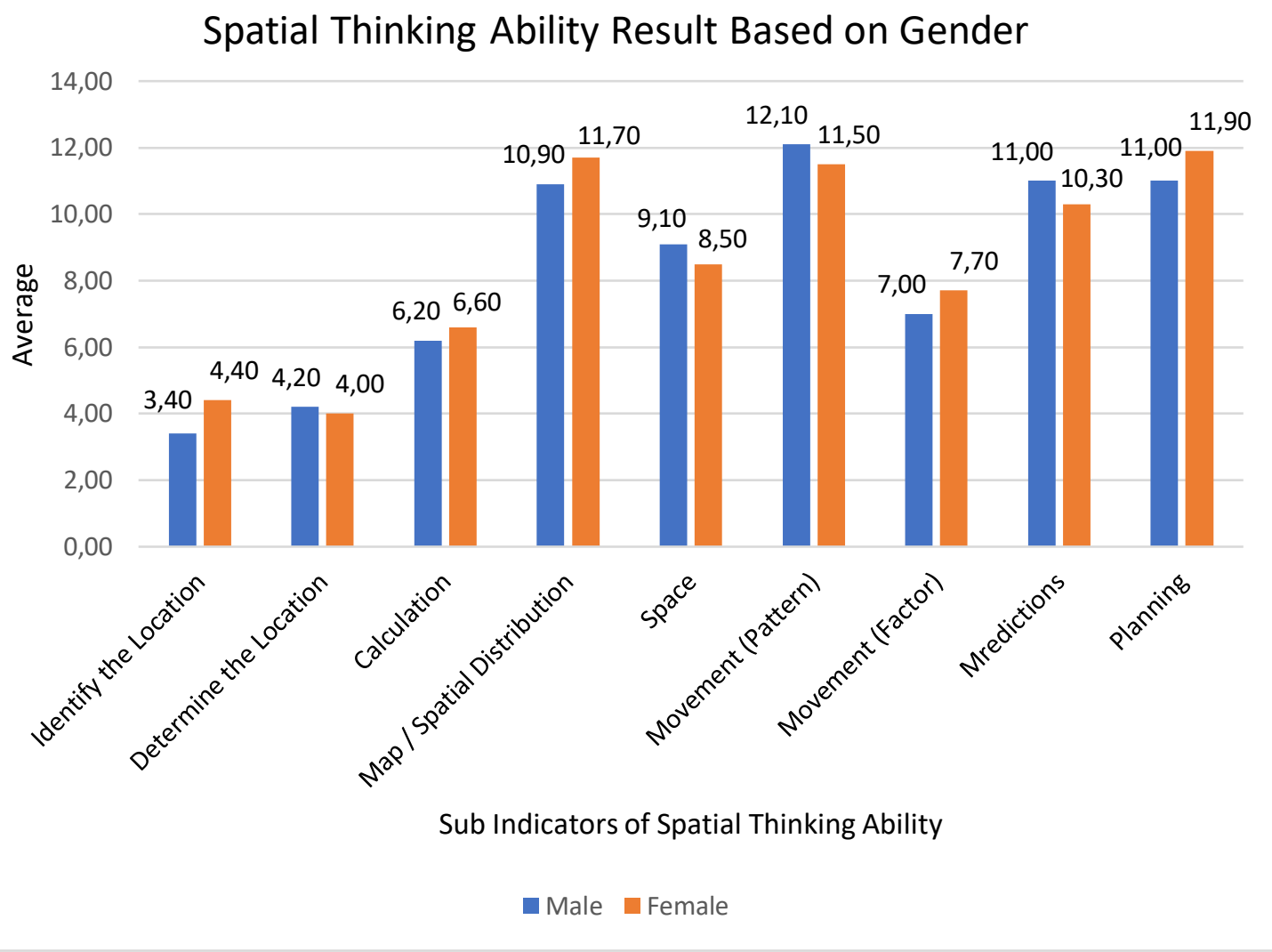

Figure 3. Diagram of the indicators achievement results of spatial ability based on the type of gender

Table 7

The Results of the Statistical Test of Gender Differences in Spatial Thinking

\begin{tabular}{cc}
\hline Tests & Spatial Thinking Ability \\
\hline Mann-Whitney U & 417.500 \\
\hline Wilcoxon W & 742.500 \\
\hline Z & -.809 \\
\hline Asymp. Sig. (2-tailed) & .419 \\
\hline
\end{tabular}

From table 7 which is based on gender shows that the differences in the ability of spatial thinking among the male students with the female is not statistically proven, because both have a mutual advantage in solving the problem. But how is the difference of spatial thinking skills of students in urban and rural environment when viewed from the gender? Are male students in the city better than male students in rural environment or vice versa? Such is the case with female students, whether the female students in urban environment are better or vice versa. As for the results of the analysis can be seen in the table 8 below.

Table 8

The Statistical Test Results of Differences in Spatial Thinking Ability of Male and Female Students in Urban and Rural Environments

\begin{tabular}{ccc}
\hline Tests & $\begin{array}{c}\text { Male Students } \\
\text { in Urban and Rural }\end{array}$ & $\begin{array}{c}\text { Female Students } \\
\text { in Urban and Rural }\end{array}$ \\
\hline Mann-Whitney U & 47.000 & 39.000 \\
\hline
\end{tabular}


Purwanto, et al. (2021). The spatial thinking ability students on the character of urban and rural.....

\begin{tabular}{ccc}
\hline Wilcoxon W & 125.000 & 249.000 \\
\hline $\mathrm{Z}$ & -1.689 & -4.131 \\
\hline Asymp. Sig. (2-tailed) & .091 & .000 \\
\hline Exact Sig. [2*(1-tailed Sig.)] & $.098 \mathrm{~b}$ & $.000 \mathrm{~b}$ \\
\hline
\end{tabular}

The results of statistical tests as shown in table 8 above indicates that there is no difference between male students within the urban and rural school on the ability of spatial thinking. Both spatial thinking skills are equally strong. It is inversely proportional to the female students, where female students in urban have the ability to think spatially stronger if compared to the students of the rural school environment.

\section{Result and Discussion}

\section{The Difference in Spatial Thinking Character of The Students Judged from The Character} of The School in Urban and Rural Environments

Student excellence in the urban environment is not caused by the use of representation tool, but more by the mastery of the spatial concept content. The complexity of the environment in urban requires students to be directly involved in the life to solve the population problem. The congestion, as one of the impacts of population density is a problem faced by city dwellers. Students in urban environment, in everyday life, have been involved directly in this problem. This strengthen the ability of students spatial thinking in solving the population problem. These findings indicate that it is not always the good mastery of geospatial technologies (Bodzin, 2011), have implications on high spatial thinking ability. Such case with the frequent use of representation tools (Ishikawa, 2016), the high literacy of geospatial technology (Moorman \& Crichton, 2018), is not always able to solve the problem better. Field experiences provide implications on the understanding ability of spatial concept, the use of representation tools and reasoning in solving the problem. In accordance with previous studies that field learning provide the positive implications of the student learning results (Sumarmi et al., 2020), it also has a positive influence on the ability to solve problems based on site aspects (Muffato \& Meneghetti, 2020). This means that students learn geography not only in the formal classroom but also through informal interaction with their environment (Hardwick \& Shelley, 1999; Yang \& Chen, 2010).

The character of spatial thinking skills of the students in the environment of rural schools excels in the use of representation tools, Google Earth. But these advantages are not functioning optimally because statistically they are inferior to the student in the urban environment. Less complex problems of the rural population cause the students not much involved in solving the population problems and eventually have less field experience. The lack of experience indicates that the students less master the content. If the high technology literacy is not balanced with the mastery of content will make students difficult to develop the ability to think. These two elements have a strong influence for students in building the capacity of thinking.

On the other hand, the characteristics of the advantages of rural students in using Google Earth as a representation tool and the absence of differences in the ability of spatial thinking in statistics show that Google Earth as the geospatial technology has 
become a universal communication tool. The pros of geospatial technology in serving the latest real world data information quickly and interactively without the limits of space and time has had a positive effect on the ability of spatial thinking society (Solari, Demirci $\&$ Van der Schee, 2015). The habit of students in using technology and geospatial information (Urfan, 2017), has changed the habits of the people to do spatial thinking.

The transformation of geospatial technology in a large scale, has been able to affect the daily life of the community (Jia et al., 2019). In the world of students education in the era of 21 st century, learning has undergone a lot of technology evolution, the existence of computer and digital technology has made students have different ways of learning (Patterson, 2007). The mastery of technology on the learning process of those two regional characteristics is assessed evenly along with the development of technology that has no boundaries of space and time. This condition is believed to be the cause of the absence of differences in the spatial thinking ability among the students within the urban and rural school.

Google Earth as a geospatial technology, in addition to its advantages, has a limited space as a representation tool when compared to the Geographic Information System (GIS). However, Google Earth application can be used as a tool of relevant representation in helping students practicing spatial thinking skills (Patterson, 2007). Relevant information obtained from the presentation of Google Earth geospatial information that contains data about the components of spatial structure such as location, region which are presented temporally. Understanding a good spatial concept can affect students in thinking spatially. When students are able to understand the concept of space well, students easily find and understand other concepts such as location, identity, region, size, and time (Golledge, 2002).

The Difference in the Spatial Thinking Character of Students Reviewed from Gender Perspective Based on the Character of the Urban and Rural School Environments

To see the extent to which the consistency of the character of the environment affect the differences in the ability of spatial thinking then it needs to be strengthened with a review of other parameters. Gender is a parameter that is commonly used to see the ability of spatial thinking consistently. Although men tend to have a powerful spatial thinking (Reilly \& Neumann, 2013). The results in this study showed no differences in the ability of spatial thinking between the male and female students. These findings are in line with the opinion stated by Linn \& Petersen (1985), for whom gender has no specific relation to spatial ability. Although in particular, the gender gap in the cognitive elements can be noticed from the ability to solve spatial problems (Reilly \& Neumann, 2016). These findings show that male is not always superior in spatial thinking despite gender biologically affect the personality of a person to do spatial thinking skills. However there are other factors that also influence people to do spatial thinking, namely the influence of the social environment and spatial experience (Newcombe et al., 1983; Yang \& Chen, 2010). It means the spatial thinking ability is influenced by many factors (Hardwick et al., 2000). 
Although this study found that no differences confirmed in the ability of spatial thinking among the male and female students on both environments, but specifically, both of them have the characteristics of spatial thinking skills. Female students tend to be strong in the mastery of spatial concept when compared to male students. Ability in stringing sentences and make the relationship to of spatial concept logically poses a causal relationship with a better quality of work, which is the characteristics of the female students in spatial thinking. It differs with the male students which is superior in spatial thinking in technical terms. This is in accordance to the opinion of Montello which stated that male has more role in the field activity in and confident in determining the location, whereas women act more on the route determination and finding important region strategies (Montello et al., 2010). The intent of the Montello's opinion illustrates that men tend to be superior in field activities while the women excel in the spatial concept.

The difference in the characteristics is due to male students has a mental map that is better if compared with female students. The mental map is related to the imagination of visual spatial owned by male students. This opinion is strengthened with the statement of Yilmaz who stated that biologically, human brain has two parts, the right and the left brain. The right hemisphere is associated with the ability of visual-spatial and left hemisphere is associated with language and verbal ability. Men tend to have a big development in the right hemisphere which causes male to be more dominant in the imagination of visual spatial than women (Yilmaz \& Yilmaz, 2017).

To see a further difference in the spatial thinking skills between male students within urban and rural school as well as female students within the urban and rural environments, it can be seen from the results of statistical tests with Mann Whitney. The absence of differences in the ability of spatial thinking among the male students in urban and schools. This result is inversely proportional to the results of the statistical test showing the differences in spatial thinking skills between female students in urban and rural environments.

Based on these findings, it can be concluded that this research, between the school environment and gender did not affect the spatial thinking skills of the students significantly. The development of information is so rapid, and the habit of the students themselves that affect it. As the explanation of Hattie (2015) that the success of the students in the learning, $51 \%$ depends on the student, $30 \%$ of teachers, and the rest is environmental factors. This means that the success of students in spatial thinking is highly dependent on the mastery of content, technology and the way students learn. Strong mastery of geospatial technology does not guarantee a better ability to think spatially if it is not supported with other components.

Based on the results of the first research, the calculation of the statistical t-test on the of spatial thinking skills of students in an urban and rural environments shows the value of sig. $=0.000$ and 0.002 , respectively. This means that there are no differences in the ability of spatial thinking among the students in urban and rural school environments. There is different level of significance though very small, so that both are included in the significantly high. Urban environment is more complex and is able to affect the spatial 
ability despite small. This complexity causes students to practice a lot of spatial thinking skills for going to school, because of the traffic density in the city. Second, the t-test results of male and female students are not proven statistically in affecting the characteristics of spatial thinking skills, shown by the level of sig. $=0.419$. It means that there are no differences in the ability of spatial thinking among the male and female students. However, if reviewed from the characteristics of urban and rural environment, male and female students has different characteristics of spatial thinking skills. Results of statistical Mann Whitney t-test obtained value of sig. $=0.91$ for male students and sig. $=$ 0.000 for female students. From the results of in-depth analysis shows no differences in the ability of spatial thinking between male students in urban and rural environment. It differs with female students which significantly showed no difference in thinking skills between those who are in urban and rural environments. Female students of the city have the powerful spatial thinking ability shown with the strength on 5 thinking indicators namely spatial location, calculation, region, movement, and prediction. This means that the character of the environments and gender differences do not always affect the ability of spatial thinking because it is proved inconsistent.

\section{Suggestions}

Recommendation for further research that needs to be done is to do a deeper study of a variety of environmental conditions, background, social culture, in influencing the differences in the ability of spatial thinking. Similarly, more research can be done in the context of the qualitative, quantitative, as well as development research.

Recommendation for applicants that the implementation of learning to determine spatial thinking ability should use a combination of other representative tools, such as digital maps, photo images, and others. the implementation of learning at the stage of students making maps, can use the GIS application so that the results are better. In addition, future learning can be done online, by combining e-learning with web-GIS to explore students' spatial thinking ability.

\section{References}

Bailey, J. E., Whitmeyer, S. J., \& De Paor, D. G. (2012). Introduction: The application of Google Geo Tools to geoscience education and research. Special Paper of the Geological Society of America, 492. https://doi.org/10.1130/2012.2492(00)

Battista, M. T. (2012). Spatial Visualization and Gender Differences in High School Geometry. Differences, 21(1), 47-60.

Bednarz, R. S., \& Lee, J. (2011). The components of spatial thinking: Empirical evidence. Procedia - Social and Behavioral Sciences, 21, 103-107. https://doi.org/10.1016/j.sbspro.2011.07.048

Belgiu, M., Strobl, J., \& Wallentin, G. (2015). Open geospatial education. ISPRS International Journal of Geo-Information, 4(2), 697-710. https://doi.org/10.3390/ijgi4020697

Birgili, B. (2015). Creative and Critical Thinking Skills in Problem-based Learning Environments. Journal of Gifted Education and Creativity, 2(2), 71-80. https://doi.org/10.18200/JGEDC.2015214253 
Bodzin, A. M. (2011). The implementation of a geospatial information technology (GIT)supported land use change curriculum with urban middle school learners to promote spatial thinking. Journal of Research in Science Teaching, 48(3), 281-300. https://doi.org/10.1002/tea.20409

Bosco, A., Longoni, A. M., \& Vecchi, T. (2004). Gender effects in spatial orientation: Cognitive profiles and mental strategies. Applied Cognitive Psychology, 18(5), 519-532. https://doi.org/10.1002/acp.1000

Umanailo, M. Chairul Basrun. (2016). Ilmu sosial budaya dasar. Namlea: FAM Publishing.

Elbay, S. (2020). A Foundational Perspective for Spatial Thinking in Relation to Social Studies Curriculum and Middle-School Textbooks in Turkey. Review of International Geographical Education Online, 10(2), 30-57. https://doi.org/10.33403/rigeo.616984

Erdoğan, G. (2019). Identifiying Urban Fringe Spatial Character with Fractal Analysis: AkhanDenizli. E-Journal of New World Sciences Academy, 14(2), 11-17. https://doi.org/10.12739/nwsa.2019.14.2.e0045

Gis, G. (2008). GIS Concepts. Open Source GIS: A Grass GIS Approach, 7-21. https://doi.org/10.1007/1-4020-8065-4_2

Golledge, R. G. (2002). The nature of geographic knowledge (annual address of the Past President of the AAG). Annals of the Association of American Geographers, 92(1), 1-14. https://doi.org/10.1186/2049-6958-9-35

Goodchild, M. F. (2011). Spatial thinking and the GIS user interface. Procedia - Social and Behavioral Sciences, 21, 3-9. https://doi.org/10.1016/j.sbspro.2011.07.002

Hardwick, S. W., Bean, L. L., Alexander, K. A., \& Shelley, F. M. (2000). Gender vs. Sex differences: Factors affecting performance in geographic education. Journal of Geography, 99(6), 238-244. https://doi.org/10.1080/00221340008978974

Hardwick, S. W., \& Shelley, F. M. (1999). Gender and Geographic Education. Journal of Geography, 98(6), 247-249. https://doi.org/10.1080/00221349908978937

Hattie, J. (2015). The Applicability of Visible Learning to Higher Education. Scholarship of Teaching and Learning in Psychology, 1(1), 79-91. http://dx.doi.org/10.1037/st10000021

Heffron, S. G. (2012). GFL2! The Updated Geography for Life: National Geography Standards, Second Edition. Geography Teacher, 9(2), 43-48. https://doi.org/10.1080/19338341.2012.679889

Ishikawa, T. (2016). Spatial thinking in geographic information science: Students' geospatial conceptions, map-based reasoning, and spatial visualization ability. Annals of the American Association of Geographers, 106(1), 76-95. https://doi.org/10.1080/00045608.2015.1064342

Jackson, P. (2006). Thinking Geographically. Geographical Association, 91(3), 199-204.

Jia, P., Xue, H., Yin, L., Stein, A., Wang, M., \& Wang, Y. (2019). Spatial Technologies in Obesity Research: Current Applications and Future Promise. Trends in Endocrinology and Metabolism, 30(3), 211-223. https://doi.org/10.1016/j.tem.2018.12.003

Jo, I., Hong, J. E., \& Verma, K. (2016). Facilitating spatial thinking in world geography using Web-based GIS. Journal of Geography in Higher Education, 40(3), 442-459. https://doi.org/10.1080/03098265.2016.1150439

King, M. J., Katz, D. P., Thompson, L. A., \& Macnamara, B. N. (2019). Genetic and environmental influences on spatial reasoning: A meta-analysis of twin studies. Intelligence, 73(December 2018), 65-77. https://doi.org/10.1016/j.intell.2019.01.001 
Lauer, J. E., Yhang, E., \& Lourenco, S. F. (2019). The development of gender differences in spatial reasoning: A meta-analytic review. Psychological Bulletin, 145(6), 537-565. https://doi.org/10.1037/bul0000191

Linn, M. C., \& Petersen, A. C. (1985). Emergence and characterization of sex differences in spatial ability: A meta-analysis. Child Development, 56(6), 1479-1498. https://doi.org/10.1111/j.1467-8624.1985.tb00213.x

Marsh, M., \& Alagona, P. S. (2018). Barron's AP Human Geography with Online Tests. Barrons Educational Series.

Metoyer, S., \& Bednarz, R. (2016). Spatial Thinking Assists Geographic Thinking: Evidence from a Study Exploring the Effects of Geospatial Technology Spatial Thinking Assists Geographic Thinking: Evidence from a Study Exploring the Effects of Geospatial Technology. Journal of Geography, 1341(May). https://doi.org/10.1080/00221341.2016.1175495

Montello, D. R., Lovelace, K. L., Golledge, R. G., \& Self, C. M. (1999). Sex-related differences and similarities in geographic and environmental spatial abilities. Annals of the Association of American Geographers, 89(3), 515-534. https://doi.org/10.1111/00045608.00160

Moorman, L. A., \& Crichton, S. (2018). Learner Requirements and Geospatial Literacy Challenges for Making Meaning with Google Earth. International Journal of Geospatial and Environment Research, 5(3).

Mosharraf, H. M., \& Tabaeian, S. M. (2014). The importance of environmental psychology in design of educational spaces. Advances in Environmental Biology, 8(22), 766-771.

Muffato, V., \& Meneghetti, C. (2020). Knowledge of familiar environments: Assessing modalities and individual visuo-spatial factors. Journal of Environmental Psychology, 67(January). https://doi.org/10.1016/j.jenvp.2020.101387

National Research Council. (2006). Learning to Think Spatially. In National Research Council. Washington, DC: The National Academies Press. https://doi.org/10.1089/1076280041138243

Newcombe, N., Bandura, M. M., \& Taylor, D. G. (1983). Sex differences in spatial ability and spatial activities. Sex Roles, 9(3), 377-386. https://doi.org/10.1007/BF00289672

Newcombe, N. S. (2016). Thinking spatially in the science classroom. Current Opinion in Behavioral Sciences, 10, 1-6. https://doi.org/10.1016/j.cobeha.2016.04.010

Patterson, T. C. (2007). Google earth as a (not just) geography education tool. Journal of Geography, 106(4), 145-152. https://doi.org/10.1080/00221340701678032

Reilly, D., \& Neumann, D. L. (2013). Gender-Role Differences in Spatial Ability: A MetaAnalytic Review. Sex Roles, 68(9-10), 521-535. https://doi.org/10.1007/s11199-0130269-0

Reilly, David \& Neumann, David L. (2016). Visual-spatial ability in STEM education: Transforming research into practice. In Visual-spatial Ability in STEM Education: Transforming Research into Practice. https://doi.org/10.1007/978-3-319-44385-0

Sanchis-Segura, C., Aguirre, N., Cruz-Gómez, Á. J., Solozano, N., \& Forn, C. (2018). Do genderrelated stereotypes affect spatial performance? Exploring when, how and to whom using a chronometric two-choice mental rotation task. Frontiers in Psychology, 9, 1-17. https://doi.org/10.3389/fpsyg.2018.01261 
Schultz, R. B., Kerski, J. J., \& Patterson, T. C. (2008). The use of virtual globes as a spatial teaching tool with suggestions for metadata standards. Journal of Geography, 107(1), 2734. https://doi.org/10.1080/00221340802049844

Seyhan, A. (2019). Out-of-School Learning to Achieve the Spatial Perception Skills: A Case Study. Review of International Geographical Education Online, 9(3), 618-638. https://doi.org/10.33403/rigeo.601734

Sinton, D. S. (2015). Spatial thinking and GIS. CEUR Workshop Proceedings, 1557, 29-35.

Solari, O. M., Demirci, A., \& Van der Schee, J. (2015). Geospatial Technologies and Geography Education in a Changing World: Geospatial Practices and Lessons Learned. Tokyo: Springer.

Sumarmi, Bachri, S., Irawan, L. Y., Putra, D. B. P., Risnani, \& Aliman, M. (2020). The effect of experiential learning models on high school students learning scores and disaster countermeasures education abilities. Journal for the Education of Gifted Young Scientists, 8(1), 61-85. https://doi.org/10.17478/jegys.635632

Uhlenwinkel, A. (2013). Spatial Thinking or Thinking Geographically? On the Importance of Avoiding Maps without Meaning. Germany. https://doi.org/10.1553/giscience2013s294.

Urfan, F. (2017). Pengaruh Lingkungan Sekolah Terhadap Kecerdasan Spasial Peserta Didik Melalui Affordance Dan Geo-Literacy Menggunakan Analisis Jalur (Studi Kasus SMA Negeri di Kota Bandung dan Kabupaten Bandung). Jurnal Geografi Gea, 16(2), 105. https://doi.org/10.17509/gea.v16i2.3281

Xiang, X., \& Liu, Y. (2017). Understanding 'change' through spatial thinking using Google Earth in secondary geography. Journal of Computer Assisted Learning, 33(1), 65-78. https://doi.org/10.1111/jcal.12166

Yang, J. C., \& Chen, S. Y. (2010). Effects of gender differences and spatial abilities within a digital pentominoes game. Computers \& Education, 55(3), 1220-1233. https://doi.org/10.1016/j.compedu.2010.05.019

Yilmaz, B., \& Yilmaz, H. B. (2017). On the development and measurement of spatial ability. International Electronic Journal of Elementary Education, 1(2), 83-96.

Yilmaz, H. (2009). On the development and measurement of spatial ability. International Electronic Journal of Elementary Education, 1.

\section{Biographical Statements}

Purwanto PURWANTO is a doctoral program student in Department of Geography Education, Universitas Negeri Malang. Field of expertise are in Geography teaching and learning, teacher education \& training, social studies education.

Sugeng UTAYA is a professor, lecturer, and researcher at Department of Geography Education, Faculty of Social Science, Universitas Negeri Malang, Indonesia. Field of expertise are in physical geography, hydrology, and environmental geography.

Budi HANDOYO is a senior lecturer and researcher at Department of Geography Education, Faculty of Social Science, Universitas Negeri Malang, Indonesia. Field of expertise are in Geography Education.

Syamsul BACHRI is an associate professor, lecturer, and researcher at Department of Geography Education, Faculty of Social Science, Universitas Negeri Malang, Indonesia. Field of expertise are in disaster especially volcano, watershed management, and geomorphology. 
Daniar YULISTIYA is undergraduate students at Department of Geography Education, Faculty of Social Science, Universitas Negeri Malang, Indonesia. Field of expertise are geography learning.

Saiful AMIN is lecturer at Department of Social Science Education, Faculty of Tarbiyah and Teacher Training, Universitas Islam Negeri Maulana Malik Ibrahim Malang. He is studying a doctoral program in Department of Geography Education, State University of Malang. Field of expertise are in geography learning, education \& teacher training, social studies education. 